\title{
Daya hambat kombinasi madu mangga (Mangifera indica)-susu probiotik terhadap pertumbuhan Eschericia coli ATCC 6538 dan Staphylococcus aureus ATCC 8739
}

\author{
Andyanita Hanif Hermawati ${ }^{1}$, Aryati $^{2}$, Isnaeni ${ }^{3}$ \\ ${ }^{1}$ Pasca Sarjana Ilmu Kedokteran Dasar Fakultas Kedokteran Universitas Airlangga \\ ${ }^{2}$ Departemen Mikrobiologi Fakultas Kedokteran Universitas Airlangga \\ ${ }^{3}$ Departemen Kimia Farmasi Fakultas Farmasi Universitas Airlangga \\ Jalan Dharmawangsa Dalam Surabaya, Indonesia
}

Submitted: 07-04-2016

Reviewed: 02-05-2016

Accepted: 03-11-2016

\begin{abstract}
ABSTRAK
Telah dilakukan kajian tentang aktivitas hambatan kombinasi madu mangga-susu probiotik Lactobacillus acidophilus (L.a) dan Lactobacillus casei (L.c) terhadap pertumbuhan Eschericia coli ATCC 6538 dan Staphylococcus aureus ATCC 8739. Susu fermentasi dibuat dengan cara inokulasi L.a dan L.c ke dalam susu perah pada suhu $43^{\circ} \mathrm{C}$, selanjutnya diinkubasi pada suhu kamar selama 24 jam. Metode difusi agar dengan media nutrient agar digunakan untuk menilai konsentrasi hambat minimum (KHM). Hasil penelitian menunjukkan bahwa pH susu fermentasi mencapai 5. Biomassa yang dihasilkan dihitung sebagai Angka Lempeng Total (ALT) L.a dan L.c masing-masing adalah $1,3 \times 10^{7} \mathrm{cfu} / \mathrm{mL}$ dan $20,7 \times 10^{13} \mathrm{cfu} / \mathrm{mL}$. Diameter zona hambat kombinasi madu mangga-susu fermentasi L.c menunjukkan daya hambat maksimal terhadap E. coli dan $S$. aureuspada perbandingan 1:9, menghasilkan KHM masing-masing sebesar $10 \%$ and 5\%. Kombinasi madu mangga-susu fermentasi L.c menunjukkan daya hambat maksimal terhadap E.coli dan S.aureus pada perbandingan2:8 dengan KHM masing-masing sebesar $6,25 \%$ dan $3,125 \%$.
\end{abstract}

Kata kunci: Madu mangga, Lactobacillus acidophilus, Lactobacillus casei, aktivitas antibakteri, Eschericia coli and Staphylococcus aureus

\begin{abstract}
Growth inhibitory activity of combination of mango honey-probiotic milk produced by Lactobacillus acidophilus (L.a) and Lactobacillus casei (L.c) against E. coli and S. aureus has been studied. The fermented milk was prepared by inoculating each probioticin milk at $43^{\circ} \mathrm{C}$ and then incubated at room temperature for 24 hours. Diffusion agar technique by using nutrient agar media was used to assess the minimum inhibition concentration (MIC). Result of the research showed that $\mathrm{pH}$ of fermentation broth of the probiotic milk reached 5. Biomass obtained that calculated by Total Plate Count of $L . a$ and $L . c$ was $1.3 \times 10^{7} \mathrm{cfu} / \mathrm{mL}$ and $20.7 \times 10^{13} \mathrm{cfu} / \mathrm{mL}$ respectively. Inhibition zone diameter ofthe mangohoney-L.c showed an optimum antimicrobial effect against tested bacteria at 1:9 ratio. The MIC value against $E$. coli and $S$. Aureus was $15.7 \pm 6,1 \mathrm{~mm}$ and $13.3 \pm 3.0 \mathrm{~mm}$ respectively. The activity of mango honey- $L$. aexhibite dan optimum antimicrobial effect against tested bacteria at $2: 8$. The MIC value against $E$. coli and $S$. Aureuswas $14,7 \pm 1,1 \mathrm{~mm}$ and $13.3 \pm 1.3 \mathrm{~mm}$ respectively.
\end{abstract}

Keyword: Mango honey, Lactobacillus acidophilus, Lactobacillus casei, antibacterial activity, Eschericia coli and Staphylococcus aureus

Penulis korespondesi:

Isnaeni

Departemen Kimia Farmasi Fakultas Farmasi Universitas Airlangga

Jalan Dharmawangsa Dalam Surabaya, Indonesia

Email: isna.yudi@gmail.com 


\section{PENDAHULUAN}

Madu adalah cairan manis yang berasal dari nektar tanaman yang diproses oleh lebah menjadi madu dan tersimpan dalam sel-sel sarang lebah (Anonim, 2004). Produksi dan tipe madu yang dihasilkan oleh lebah madu tergantung pada bunga vegetatif alami dan musim bunga, sehingga bunga nektar yang dikumpulkan lebah untuk menghasilkan madu juga akan memberikan karakter yang berbeda pula. Hermawati et al., (2015) telah melaporkan perbedaan aktivitas daya hambat madu randu, karet, dan mangga terhadap S. aureus dan E.coli. Menurut Mundo et al. (2004), madu juga dapat menghambat pertumbuhan bakteri patogen pada makanan seperti Listeria monocytogenes. Nadhilla (2014) juga melaporkan aktivitas madu terhadap S. auresus dan senyawa aktif dalam madu seperti asam glukonat, hidrogen peroksida dan flavonoid

Madu dipercaya sebagai makanan yang menyehatkan (Antony et al., 2006; Kumar et al., 2010, Ajibolaet al., 2012). Masyarakat sering mengkonsumsi madu ditambah susu atau produk olahan susu. Menurut Putri dkk. (2009), produk susu fermentasi yang sudah dikenal di Indonesia antara lain yogurt, susu asam, kefir dan minuman susu fermentasi berperisa. Sejak tahun 2003 muncul beberapa pesaing di industri minuman susu fermentasi yang mengandung probiotik. Prospektif probiotik di bidang industri juga telah dilaporkan (Anal, 2007).

Probiotik merupakan satu atau campuran kultur mikroorganisme hidup yang diberikan kepada manusia atau hewan baik dalam bentuk sel kering atau sebagai produk fermentasi yang dapat memberikan efek menguntungkan pada host melalui peningkatan jumlah flora normal tubuh. Bakteri asam laktat (BAL) merupakan probiotik yang paling banyak memberikan efek menguntungkan pada saluran pencernaan manusia (Annuket al., 2009). Bakteri ini merupakan Gram-positif yang hidup pada kondisi non-aerob, tetapi juga dapat hidup dalam keadaan aerob (Holzapfel et al., 2001; Anal and Singh, 2007).

Kemampuan BAL dalam menanggulangi penyakit infeksi dapat disebabkan oleh produk metabolisme yang dihasilkan antara lain senyawa asam laktat, hidrogen peroksida $\left(\mathrm{H}_{2} \mathrm{O}_{2}\right)$ dan asam-asam organik lain serta senyawa peptida antimikroba yang disebut bakteriosin. Metabolit ini memegang peranan paling penting dalam menanggulangi infeksi. Kelebihan bakteriosin dibandingkan senyawa antimikroba lain adalah bekerja secara selektif, aman dan dapat mengatasi resistensi (Marshall, 2003). Acidocin A dan Lactasin adalah contoh bakteriosin yang dihasilkan oleh Lactobacillus acidophilus (L.a), sedangkan caseicin adalah bakteriosin yang dihasilkan oleh Lactobacillus casei (L.c).Bakteriosin adalah peptide antibakteri yang disintesis secara ribosomal, dihasilkan oleh sejumlah bakteri dan mempunyai pengaruh bakterisidal dan atau bakteriostatik terhadap bakteri yang mempunyai hubungan dekat terhadap bakteri penghasilnya (Isnaeni et al., 2015).

Susu probiotik dan madu masing-masing mempunyai sifat antibakteri dengan mekanisme yang berbeda (Hermawati, 2015; Isnaeni et al., 2015). Susu probiotik menghasilkan bakteriosin dan asamasam organik sebagai antibakteri, bahkan dapat menghambat pertumbuhan methicillin-resistant Staphylococcus aureus (MRSA) dan extended strain betalactamase ESBL (Barbara et al., 2010,Isnaeni dan Mertaniasih, 2015). Kombinasi susu probiotik L. acidophilus dan L.casei dilaporkan mampu mengatasi masalah diare (Nelintong et al., 2015). Madu juga mampu menghambat pertumbuhan bakteri patogen seperti E. coli, Listeria monocytogenes, dan S. aureus (Mundo et al, 2004; Hermawati, 2015), karena kadar gula reduksi dan sukrosanya yang tinggi (Anonim, 2004). Pembuatan kombinasi susu probiotik dan madu bertujuan untuk meningkatkan aktivitas antibakteri dan memadukan aktivitas lain yang dimiliki susu probiotik atau madu.

Kemampuan kombinasi madu dan susuprobiotik dalam menghambat pertumbuhan mikroba patogen menarik untuk dikaji.Penelitian ini diharapkan mampu menghasilkan temuan bermakna terkait pemanfaatan bahan alam dan mikroba sebagai sumber senyawa bioaktif.

\section{METODE PENELITIAN}

\section{Alat dan Bahan}

Alat yang digunakan dalam penelitian ini adalah neraca analitikcolony counter, jangka sorong digital, spectrophotometer, shaker incubator (Mermet), incubator (Mermet), vortex, micro pipette (efendorf), autoclave, alat gelas. Bahan yang digunakan dalam penelitian ini adalah madu mangga diperoleh dari petani madu di area perkebunan mangga daerah Pasuruan, Jawa Timur, diambil pada bulan Fabuari-Maret 2015. Probiotik yang digunakan adalah Lactobacillus acidophilus FNCC0051dan 
Lactobacillus casei diperoleh dari isolat referen Fakultas Sains dan Teknologi, Departemen Kimia Farmasi, Fakultas Farmasi Universitas Airlangga, dibiakkan dalam media deMann Rogosa and Sharpe (MRS) broth. Escherichia coli ATCC 6538 dan Staphilococcus aureus ATCC 8739 yang digunakan sebagai bakteri uji pada penelitian ini diperoleh dari kultur persediaan di Ruang Praktikum Mikrobiologi, Departemen Kimia Farmasi, Universitas Airlangga, dibiakkan dalam media Nutrient Agar.

\section{Jalannya penelitian \\ Pembuatan susu probiotik}

Sebanyak $500 \mathrm{~mL}$ susu perah dipasteurisasi pada suhu $80-85^{\circ} \mathrm{C}$ selama 10 menit, kemudian didinginkan hingga suhu $45^{\circ} \mathrm{C}$. Sebanyak 1 mlinokulum BAL dalam MRS cairdiinokulasikan ke dalam 15 mlsusuyang sudah dipasteurisasi dan diaduk sampai homogen, kemudian diinkubasi pada suhu ruang selama 24 jam. Selanjutnya, 15mL starter BAL dalam susu dimasukkan ke dalam $200 \mathrm{~mL}$ susu yang sudah dipasteurisasi, diinkubasi (6-8) sampai didapatkan jumlah bakteri asam laktat $\geq 10^{7} \mathrm{CFU} / \mathrm{mL}$ dan pH 4,0-4,5 (Isnaeni dan Mertaniasih, 2015).

\section{Pembuatan Larutan Madu}

Ditimbang sebanyak 50,0 g madu mangga, ditambah air suling sampai $100 \mathrm{~g}$, diperoleh larutan madu 50\%, siap dikombinasi dengan susu probiotik untuk uji aktivitas.

\section{Penetapan Angka Lempeng Total (ALT)}

Sebanyak $1 \mathrm{~mL}$ susu probiotik diencerkan 10 kali dengan larutan salin hingga diperoleh enceran $10^{10}$. Dari setiap enceran diambil $1 \mathrm{~mL}$, dimasukkan ke dalam cawan petri steril, ditambah media MRS agar suhu $45-50^{\circ} \mathrm{C}$, dihomogenkan, didiamkan hingga memadat, dan diinkubasi selama 48 jam pada suhu $37^{\circ} \mathrm{C}$. Dihitung jumlah koloni pada cawan petri yang mengandung 30-300 koloni, dan dikalikan pengencerannya (Isnaeni dan Mertaniasih, 2015).

\section{Uji Aktivitas daya hambat}

Dilakukan pada media Nutrient agar dengan base layer $10 \mathrm{~mL}$ dan seed layer $8 \mathrm{~mL}$ menggunakan bakteri uji $E$. coli and $S$. aureus yang dibuat inokulum dengan transmitan $25 \%$ pada panjang gelombang $580 \mathrm{~nm}$. Sebanyak $5 \mu \mathrm{L}$ inokulum bakteri uji, ditambahkan ke dalam media perbenihan (seed layer), dikocok dengan vortex, dituangkan ke atas permukaan media dasar (base layer) dalam cawan petri, didiamkan hingga memadat. Dibuat cetak lubang, diisi dengan $50 \mu \mathrm{L}$ larutan sampel dan standar kanamisin, selanjutnya diinkubasi selama 24 jam. Diameter zona yang terbentuk di sekitar pencadang diukur (mm) (Isnaeni dan Mertaniasih, 2015).

\section{HASIL DAN PEMBAHASAN}

Madu mangga yang digunakan pada penelitian ini memiliki berat jenis 1,35, keasaman memenuhi syarat yaitu volume $0.1 \mathrm{~N} \mathrm{NaOH}<1 \mathrm{~mL}$, campuran tetap jernih, dan kadar abu $132 \mathrm{mg}$. Madu mangga memiliki warna coklat kehitaman dan $\mathrm{pH}$ sekitar 5. Nilai $\mathrm{pH}$ madu variatif, tergantung jenis madu. Madu hutan, madu randu, madu rambutan, dan madu kelengkeng berturut-turut memiliki $\mathrm{pH}$ sebesar 3,78; 3,56; 3,81; dan 4,09 (Hermawati, 2015).

Ditinjau dari harga ALT, L. a dan L.c dalam susu probiotik masing-masing adalah $1,3 \times 10^{7}$ $\mathrm{cfu} / \mathrm{mL}$ dan $20,7 \times 10^{3} \mathrm{cfu} / \mathrm{mL}$, memenuhi persyaratan SNI, jumlah bakteri starter untuk probiotik $\geq 10^{7}$ koloni/g (Anonim, 2004). Zona hambat tertinggi dihasilkan oleh kombinasi madu mangga-susu L.c dengan perbandingan 1:9 sebesar 15,7 $\pm 6,1$ dan 13,3 $\pm 3,0 \mathrm{~mm}$ masing-masing terhadap $E$. coli dan $S$. aureus. Zona hambat tertinggi dihasilkan oleh kombinasi madu mangga-L.a dengan perbandingan 2:8 sebesar 14,7 $\pm 1,1 \mathrm{~mm}$ dan 13,3 \pm 1,3 $\mathrm{mm}$ masing-masing terhadap E. coli dan $S$. aureus (Tabel I).

Konsentrasi hambat minimum (KHM) larutan madu mangga diperoleh pada 6,25\% dan 7,5\% dengan diameter zona hambat 9,2 $\pm 0,6 \mathrm{~mm}$ dan $14 \pm 3,0 \mathrm{~mm}$ masing-masing terhadap $E$. coli dan $S$. aureus. Konsentrasi hambat minimal susu probiotik L.a dicapai pada 3,125\% dan 2\% dengan diameter zona sebesar 11,5 mm dan 11,0 mm masing-masing terhadap E. coli dan S. aureus, sedangkan L.c dicapai pada $2 \%$ dengandiameter zona $10 \mathrm{~mm}$ baik terhadap E. coli maupun S. aureus (Gambar 1). Konsentrasi hambat minimal kombinasi madu mangga-L.a dan madu-mangga-L.c sebesar $10 \%$ dan $6,25 \%$ terhadap $E$. coli, 5\% dan 6,25\% terhadap S. aureus. (Gambar 2 dan Gambar 3). 
Tabel I. Hasil pengukuran diameter zona hambat kombinasi larutan madu mangga $50 \%$-susu probiotik L.a dan larutan madu mangga $50 \%$-susu probiotik L.c pada berbagai rasio konsentrasi (\%) terhadap Eschericia coli dan Staphylococcus aureus

\begin{tabular}{ccccc}
\hline \multirow{2}{*}{ Rasio } & \multicolumn{4}{c}{ Rerata diameter zona+SD $\mathbf{( m m )}$} \\
\cline { 2 - 5 } & \multicolumn{2}{c}{ Kombinasi } & \multicolumn{2}{c}{ Kombinasi } \\
madu 50\%-probiotik $\boldsymbol{~} . \boldsymbol{a}$ & madu 50\% & -poli & S.aureus & E.coli \\
& S.aureus & $14,3 \pm 1,1$ & $13,3 \pm 3,0$ & $15,7 \pm 6,1$ \\
$9: 1$ & $13,3 \pm 1,1$ & $14,7 \pm 1,1$ & $13,3 \pm 1,1$ & $15,0 \pm 5,2$ \\
$8: 2$ & $13,3 \pm 1,3$ & $12,5 \pm 2,6$ & $12,0 \pm 2,0$ & $14,0 \pm 6,0$ \\
$7: 3$ & $11,3 \pm 1,3$ & $13,6 \pm 1,9$ & $11,5 \pm 1,0$ & $12,7 \pm 4,1$ \\
$6: 4$ & $12,8 \pm 1,5$ & $12,3 \pm 1,1$ & $11,3 \pm 1,1$ & $13,0 \pm 4,0$ \\
$5: 5$ & $11,7 \pm 1,1$ & $12,0 \pm 2,0$ & $11,3 \pm 1,5$ & $13,3 \pm 3,0$ \\
$4: 6$ & $11,7 \pm 1,1$ & $12,3 \pm 1,1$ & $10,7 \pm 1,1$ & $11,8 \pm 2,5$ \\
$3: 7$ & $11,7 \pm 1,1$ & $12,0 \pm 0,0$ & $11,5 \pm 1,0$ & $13,5 \pm 5,5$ \\
$2: 8$ & $11,3 \pm 1,3$ & $12,3 \pm 1,1$ & $11,3 \pm 1,1$ & $13,0 \pm 4,0$ \\
$1: 9$ & $11,5 \pm 1,0$ & $15,7 \pm 1,1$ & $15,7 \pm 3,0$ & $15,5 \pm 5,1$ \\
$10: 0$ & $14,3 \pm 1,1$ & $15,7 \pm 3,0$ & - & - \\
$0: 10$ & $14,8 \pm 2,8$ & - & $15,3 \pm 2,8$ & $15,8 \pm 0,5$ \\
$0: 10$ & - & - &
\end{tabular}

Keterangan: Setiap percobaan dilakukan sebanyak tiga kali. Pada rasio 9:1 dan 8:2 dihasilkan diameter zona hambat masing-masing terhadap $S$. aureus dan E. colirelatif lebih besar dibandinkan rasio yang lain.
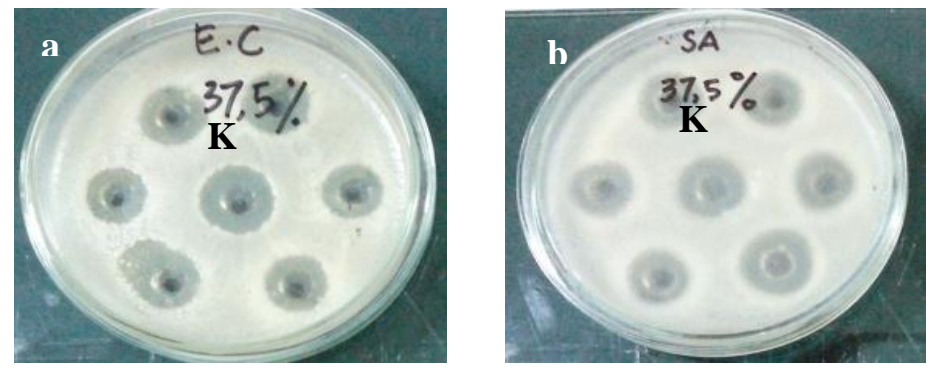

Gambar 1. Daya hambat larutan madu mangga 37,5\% terhadap Eschericia coli (a) dan Staphylococcus aureus (b) dan larutan standar kanamisin 62,5 ppm (K)
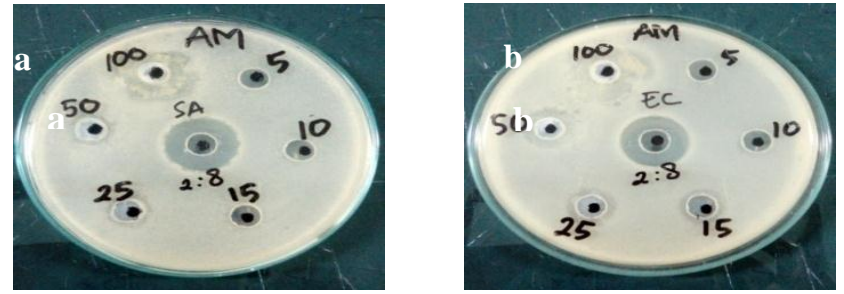

Gambar 2. Daya hambat kombinasi larutan madu mangga (50\%)-susu probiotik L.acidophilus 8:2 pada konsentrasi $100 \%, 50 \%, 25 \%, 15 \%, 10 \%$ dan 5\% terhadap Staphylococcus aureus (a) dan Eschericia coli (b) dan larutan standar kanamisin 62,5 ppm (K)

Kombinasi madu-susu probiotik menunjukkan KHM lebih rendah dibandingkan susu probiotik, namun lebih tinggi dibandingkan KHM larutan madu 50\%. Fenomena ini dapat dijelaskan karena adanya interaksi antara susu probiotik dengan larutan madu. Pada konsentrasi 62,5\% larutan madu sudah memberikan daya hambat terhadap bakteri uji. Larutan madu yang dipergunakan untuk formula kombinasi dibuat 50\% (lebih besar dari KHM), dikhawatirkan pada konsentrasi 100\%, kandungan gula reduksi 65\% (dinyatakan sebagai glukosa) dan sukrosa (50\%) (Anonim, 2004) cukup tinggi untuk menghambat pertumbuhan dan aktivitas probiotik. Pada konsentrasi 37,5\% larutan madu mangga memberikan daya hambat setara dengan larutan standar kanamisin 6,25 ppm (Gambar 1). Kompetisi nutrisi/makanan antara Lactobacillus dengan bakteri uji juga dapat menghambat pertumbuhan probiotik. Senyawa antibakteri yang dihasilkan oleh larutan madu dapat menghambat pertumbuhan bakteri yang terdapat dalam susu probiotik. Daya antibakteri madu disebabkan oleh kandungan senyawa aktif dalam 
madu, antara lain flavonoid dan karbohidrat konsentrasi tinggi dengan mekanisme antibakteri yang terdiri dari tekanan osmosis, keasaman, dan adanya senyawa inhibine (Patton et al., 2006; Mekawey, 2010).

Bakteri asam laktat yang memproduksi bakteriosin bersifat sebagai bakterisidal terbukti sangat bermafaat untuk mengembangkan keamanan produk fermentasi pangan. Sampai saat ini baru ditemukan satu bakteriosin yang dihasilkan bakteri asam laktat dan telah digunakan pada produk pangan, yaitu nisin.Lactobacillus acidhopillus dapat memproduksi bakteriosin yakni Acido-philucin A. Efek antimikroba $L$. $a$ dapat disebabkan oleh aktivitas bakteriosin dan asam-asam organik lain serta adanya kompetisi mikroba dengan bakteri lain. Berbagai aktivitas yang ditunjukkan oleh probiotik antara lain sebagai penurun cholesterol (Belviso et al., 2009), anti kanker kolon (Bradyet al., 2000), dan anti dermatitis (Betsi et al., 2008) sangat menguntungkan bila dikombinasi dengan madu.

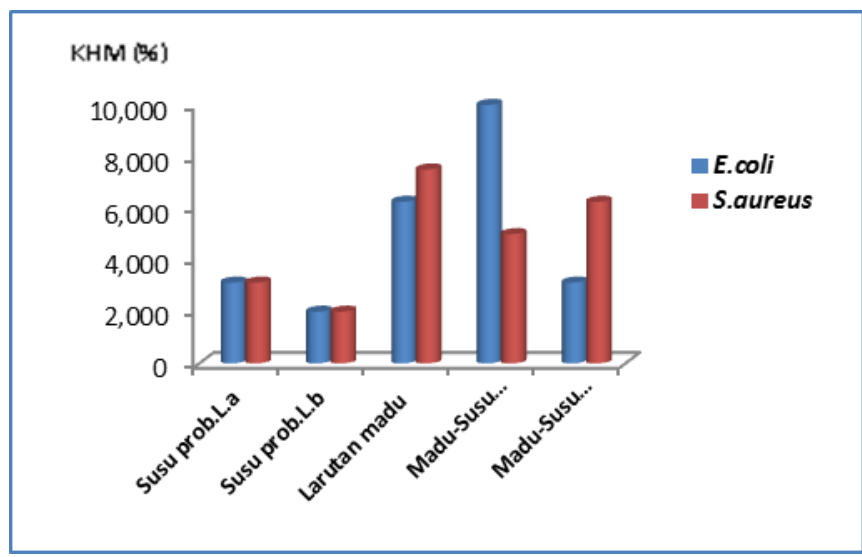

Gambar 3. Rerata KHM (\%) susu probiotik L.a, susu probiotik L.c, larutan madu mangga 50\%, larutan madu-susu prob L.a (8:2), dan larutan madu-susu prob $L . c$ (9:1), terhadap Staphylococcus aureus dan Eschericia coli

Kombinasi madu-susu probiotik L.a dan L.c dengan rasio 2:8 dan 1:9 dapat diusulkan dan prospektif untuk dikembangkan sebagai food supplement. Fenomena ini didukung data ALT susu probiotik L.a dan L.C masing-masing $10^{7} \mathrm{cfu} / \mathrm{mL}$ dan $10^{13} \mathrm{cfu} / \mathrm{ml}$ yang memenuhi persyaratan sediaan dengan target kerja di intestin. Syarat probiotik untuk dapat menimbulkan efek menyehatkan bagi host dengan target intestin dan menghambat bakteri patogen adalah minimal $10^{6} \mathrm{cfu} / \mathrm{mL}$ (Kailasapath, 2002). Fakta ini menjelaskan adanya produksi asam dan/atau senyawa lain seperti bakteriosin yang paling tinggi tercapai pada jam ke-24, walaupun tidak linear dengan jumlah sel probiotik yang memasuki fase decline, sehingga jumlah sel menurun pada jam ke-24. Korelasi antara produksi metabolit dan biomassa yang mengikuti pola non-growth associated dapat dijadikan referensi ketika membuat formula sediaan susu probiotik, khususnya dengan L.a dan L.c.

\section{KESIMPULAN}

Larutan madu mangga (Magnifera indica) 50\%, susu probiotik Lactobacillus acidophilus dan Lactobacillus casei, kombinasi larutan madu mangga 50\% dengan masing-masing susu probiotikmenunjukkan aktivitas antibakteri terhadap aureusATCC 8739 dan E. coli ATCC 6538.

Kombinasi susu probiotik L.a - larutan madu mangga 50\% dan L.c - larutan madu mangga 50\% menghasilkan aktivitas antibakteri maksimal terhadap S. aureus dan E. coli masing-masing pada perbandingan 2:8 dan 1:9. Konsentrasi hambat minimum kombinasi susu probiotik L.a - larutan madu mangga 50\%(2:8)terhadap E. coli dan S. aureus masing-masing 10\% dan 5\%. Konsentrasi hambat minimum kombinasi susu probiotik L.c - larutan madu mangga 50\%(1:9) terhadap E. coli dan S. aureus masing-masing $6,25 \%$ dan $3,125 \%$.

\section{UCAPAN TERIMA KASIH}

Terima kasih saya sampaikan kepada Fakultas Farmasi Universitas Airlangga yang telah menyediakan sarana dan prasarana serta fasilitas, sehingga penelitian ini dapat berjalan dengan baik.

\section{DAFTAR PUSTAKA}

Ajibola, A., Joseph P.C., Kennedy H.E., 2012, Nutraceutical values of natural honey and its contribution to human health and wealth. Nutrition and Metabolism, 9:61. 
Anal, A.K. and Singh, H., 2007, Recent advances in microencapsulationof probiotics for industrial applications and targeted delivery. Trends food Sci.Tech.18.240-251.

Annuk, H.,Shchapetova, J., Kullisaar, T., Songisepp, E., Zilmer, M., Mikelsaar M., 2009, Characterization of intestinal lactobacilli as putative probiotic candidates. Journal of Applied Microbiology, 94:403-12.

Anonim, 2004, Madu. Standar Nasional Indonesia 01-3545. Badan Standarisasi Nasional. Jakarta. Hal 56.

Antony, S., Rieck, J.R., Acton,J.C.,Han, I.Y., Halpin, E.L.,and Dawson, P.L., 2006,Effect of dry Honey on the self life of packaged Turkey slice. Poultry Science 85: 1811-1820.

Barbara, K.W., Bazoa, M., Wanda, S., 2010, Antibacterial activity of Lactobacillus acidophilus and Lactobacillus Casei against methicillin-resistant Staphylococcus aureus (MRSA). Microbiological Research 165: 674-686.

Belviso, S., Giordano, M., Dolci, P. and Zeppa, G., 2009, In vitro cholesterol-lowering activity of Lactobacillus plantarumand Lactobacillus paracaseistrains isolated from the Italian Castelmagno PDO cheese,Dairy Sci. Technol.89 : 169-176.

Betsi, G.I., Papadavid, E. and Falagas, M.E., 2008, Probiotics for the treatment or prevention of atopic dermatitis: a review of the evidence from randomized controlled trials. Am. J. Clin. Dermatol. 9(2): $93-103$.

Brady, L.J., Gallaher, D.D. and Busta, F.F., 2000, The role of probiotic cultures in the prevention of colon cancer. J. Nutr. $130: 410-414$.

Hermawati, A.H., Aryati, Isnaeni, 2015, Antibacterial activity of monofloral honeys of Ceiba pentandra, Mangifera indica, and Hevea brasiliensisagainst Staphylococcus aureus ATCC 6538 and Escherichia coli ATCC 8739, The Second International Symposium on Traditional and Alternative Medicine, 23-24,November 2015, Surabaya, Indonesia

Hermawati, A, 2015,Aktivitas kombinasi madu mangga dan susu probiotik sebagai antibakteri terhadap Staphylococcus aureus ATCC 6538 dan Eschericia coli ATCC 8739.Tesis. Fakultas Kedokteran Universitas Airlangga Surabaya.

Holzapfel, W.H., Haberer, P., Geisen, R., Björkroth, J., Schillinger, U., 2001, Taxonomy and important features of probiotic microorganisms in food and nutrition. American Journal of Clinical Nutrition, 73 (2 Suppl.), 365S-373S.

Isnaeni and Mertaniasih, N.M., 2015, Antibacterial activity of probiotic mixed culture against MRSA and ESBL. J. Chem. Pharm. Res. 7(4): 1005-1010.

Isnaeni, Poernomo, A.T., dan Nataly.F., 2015, Profil bioautogram bakteriosin dalam sediaan susu probiotik. Berkala Ilmiah Kimia Farmasi, 4(1):21-28.

Kailasapath,K, 2002, Microencapsulation of probiotics bacteria: technology and potential applications .Curr.Issues Intest. Microbiol.(3):39-48.

Kumar, K.P.S., Debjit, B., Chiranjib, Biswajit, Chandira, M.R., 2010, Medicinal uses and health benefit of honey: An Overview. J. Chem. Pharm. Res. 2(1): 385-395.

Marshall, S.H., 2003, Antimicrobial peptides : as natural atlernative to chemical antibiotics and a potential for applied biotechnology. Electron.J.Biotech.,(3): 6.

Mekawey, AAI., 2010, Evaluation the inhibitory action of Egyptian honey from various sources on fungal and bacterial growth and aflatoxins production. Ann. Agric. 55(2):221-223.

Mundo, Melissa A., Olga I. Padilla-Zakour, Randy W. Worobo, 2004, Growth inhibition of food pathogens and food spoilage organisms by selected raw honeys.International Journal of Microbiology (97): 1-8

Nadhilla, N. F, 2014, The activity of antibacterial agent of honeyagainst Staphylococcus aureus..J. Majority.(3): 7.

Nelintong, N., Isnaeni, Nasution, NE., 2015, Aktivitas antibakteri susu probiotik Lactobacilli terhadap bakteri penyebab diare (Escherichia coli, Salmonella typhimurium, Vibrio cholerae). Jurnal Farmasi dan Ilmu Kefarmasian Indonesia, 2(1): 25-30.

Patton T., Barrett J., Brennan J., Moran N., 2006, Use of a spectrophotometric bioassay for determination of microbial sensitivity to manuka honey. J. Microbiol. Methods 64(1):84-95.

Pharmaciana Vol. 6, No. 2, November 2016, Hal. 201-206 